\title{
Theoretical signposts for tracing spirituality within the fluid decision-making of a mobile virtual reality
}

\begin{abstract}
Author:
Jan-Albert van den Berg

Affiliation:

${ }^{1}$ Department of Practical

Theology, University of the

Free State, South Africa

Note:

This article was delivered as a paper at the Second Joint Conference of Academic

Societies in the Field of Religion and Theology, held at the University of KwaZuluNatal, Pietermaritzburg

Campus, South Africa, 18-22 June 2012.

This article is published in the section Practical Theology of the Society for Practical Theology in South Africa.

\section{Correspondence to:}

Jan-Albert van den Berg

Email:

vdbergja@ufs.ac.za

Postal address:

PO Box 100985, Brandhof

9324, South Africa

Dates:

Received: 27 June 2012

Accepted: 29 Aug. 2012

Published: 12 Nov. 2012

How to cite this article: Van den Berg, J-A., 2012, 'Theoretical signposts for tracing spirituality within the fluid decision-making of a mobile virtual reality', HTS Teologiese Studies/ Theological Studies 68(2), Art. \#1290, 6 pages. http:// dx.doi.org/10.4102/hts. v68i2. 1290
\end{abstract}

C 2012. The Authors. Licensee: AOSIS OpenJournals. This work is licensed under the Creative Commons Attribution License.
In the context of the interconnected world of the information age, and demarcated by a virtual existence through the use of the Internet, decision-making has become even more dynamic. In an evolving era of virtuality, with special emphasis on the increasing role of mobile communication technology, it is indicated that decision-making has become fluid. As part of the phenomenon of fluid decision-making, not only is the evolutionary character of virtual connectivity acknowledged, but the ever-increasing and important role of mobile platforms is also emphasised. In a hermeneutical practical theology of lived spirituality, focusing on the praxis of everyday living, the possible role of spirituality in informing the fluid decisionmaking processes in a mobile virtual world was traced. A qualitatively inspired analysis, using data collected from various virtual forums, was proposed. In the description of these contours, special emphasis was placed on narrative-inspired biographical accents. The research made a contribution in terms of possible new articulations of the language of faith as embodied in fluid decision-making in a mobile virtual reality.

\section{Introduction}

\section{Virtual reality and the virtues of reality}

'We lived in the country, we lived in the city, now we shall live on the Internet' (Sean Parker) (Nilesfilmfiles 2011). ${ }^{1}$

'If South Africa were a village ... what would it look like?' This was the challenging question that was once again investigated by the research company, Ipsos, in a recent follow-up of their previous famous research conducted in 2008 and 2010. Ipsos compiled their report in terms of the following questions: 'If South Africa were a single village with only 100 adult inhabitants, what would it look like? What would the people be like and what would they want from life?' (Ipsos 2012). According to this study, out of 100 people in South Africa who were interviewed, 83 people owned, rented or used a cell phone. Ironically enough, 8 out of every 10 people $(80 \%)$ have no Internet access, whilst $6 \%$ can access the Internet at work, $6 \%$ at home and $13 \%$ via cell phone. On the basis of these statistics, a reasonable and accountable prediction can be made, namely that the discrepancy between the use of cell phones and Internet usage is certainly likely to change in the nearby future.

The interesting statistics above regarding the use of communication technology, as well as the remark on the integration between cell phone and Internet usage, are supported by recent media reports focusing on how social media, especially Twitter, are being utilised in Africa. Recently released research by Portland Communications shows that $57 \%$ of all African 'tweets' are sent from mobile phones (Tweetsmarter 2012). Although South Africa is the country in Africa with the highest number of active users of Twitter, a report concerning a Kenyan village chief informing his community on important social issues, was recently broadcast worldwide. According to The Telegraph of 20 February 2012 ('Help, sheep missing'), 'tech-savvy' Francis Kariuki (47), the administrative chief of Lanet Umoja, is using Twitter as a crime-fighting tool - but also to send messages of hope and peace. Kariuki has managed to overcome the divide between cell phone and Internet usage, as discussed above, providing access to 'tweets' by making use of a thirdparty mobile phone application. Although Kariuki's official Twitter page shows 300 followers, it is estimated that a high percentage of the 28000 residents in the area receive messages that are directly and indirectly sent out by him.

The mentioned news report about the Kenyan village chief not only indicates that mobile phones have become many a person's link to the world (Sweet 2012), but also that informed and improved decision-making is embedded in an evolving understanding of the annus virtualis, or the era of

1.Sean Parker (played by Justin Timberlake) in David Finscher's award-winning film, The Social Network (2010), highlighted the far-reaching significance of Mark Zuckerberg's Facebook. 
virtuality $^{2}$ (Joubert 2010:48). Decision-making has therefore become much more volatile due to the interplay of especially communication technologies in a changing world. The validity of this challenge is further underscored if it is taken into account that, according to the Millennium Project of the United Nations (UN), and as documented in the publication entitled 2008 - State of the Future (Glenn, Gordon \& Florescu 2008:12-41), one of the current ' 15 Global Challenges' is that of how to improve the '... capacity to decide ... as the nature of work and institutions change [sic]' (Glenn et al. 2008:28-29).

In the documentation of preliminary perspectives with a view to the description of a practical theological investigation into the possible role of spirituality in the fluid decisionmaking in a mobile virtual reality, I shall use insights gleaned from a literature study, further elucidated by a proposed methodology for tracing existing examples from the era of virtuality. The intention of the article is therefore to describe the background to and motivation for a planned scientific inquiry into the possible role of spirituality in informing decision-making in a mobile virtual reality. As part of this description some outcomes of completed research associated with the project will be described. Sprouting from this description the relevance of these perspectives for the envisaged future research project will be mapped out and indicated as so-called theoretical signposts.

The two concepts of virtual reality and virtues of reality (Bedford 2002:159) will be used in structuring the research perspectives. The notion of tracing the contours of reality also ties in well with the emphasis on a hermeneutical understanding, as portrayed by the classical practical theological interpretation of the continuous movement between practice and theory (Browning 1991:41). In the articulation of these perspectives, the following specific movements and accents will receive emphasis.

\section{Movement to the practice Virtual reality (and beyond?)}

'The cell is your covenant with life; the cell is your convent in life' (Sweet 2012:n.p.).

It is a given fact that we currently find ourselves in a world characterised by 'the new social structure of the Information Age', which has resulted in 'a culture of virtuality in the global flows that transcend time and space' (Castells 2006:381). In an evolving understanding of virtuality, and in thinking ahead into the future, the traditional lines of demarcation are being eliminated (Barna 2011), since - as Graham (2003:32) points out - 'technological advance is reshaping what it means to be human.'

2.Activities usually carried out in cyberspace or on the Internet are termed virtual activity or virtuality. Cyberspace is the online world, the Internet world where communities meet' (Lesame, Sindane \& Potgieter 2012:13).

3.I concur with MacIntyre (1981:187), Dykstra and Bass (2002:22) and Volf (2002:248) who regard 'practice' as any coherent, complex, sustained, cooperative pattern of human activity, pertaining to some fundamental feature of existence, such as of human activity, pertaining to some fundamental feature of existence, such as
specific needs and conditions, which is carried out systematically over a period of specific
time.
In his well-known book, The world is flat, Friedman (2006:8) pointed out that, through significant developments brought about by various kinds of communication technology, more and more people are now able to come into contact with other people across the world. Niemandt (2009:625) refers to this factor as the 'Globalization 3.0' phenomenon, in terms of which individuals and groups can be linked, integrated and empowered in networks, from the basis of a 'flat-world platform.'

However, Leonard Sweet (2012), amongst others ${ }^{4}$, has recently made observations that further inform the understanding of a 'flat world':

Forget 'the earth is flat'. This world is fluid. To flatten the complexity of a situation is to endanger the future. The world today is a dangerous place. Some cheer that it is 'dangerously flat'. Others sneer that it is 'dangerously curved'. I claim it is dangerously fluid. (n.p.)

This 'fluid' world, embodied in various evolutionary stages of Internet development, along with the growth in the smartphone market, facilitating growing mobile Internet connectivity, forms the backdrop for the quest for improved decision-making possibilities. However - evolving from Web 2.0, which 'enables Internet users to directly engage with and construct by easily pulling together the sorts of people and information that they are interested in' (Lesame, Sindane \& Potgieter 2012:6) - the current emphasis is on the development of Web 3.0, with accents of mobile applications and so-called cloud-computing. In this regard, the influential technology research company, Gartner, has published a report indicating that by 2013 already, '33\% of business intelligence functionality will be consumed via handheld devices' (Bitterer \& Sood 2011). It can therefore rightfully be said that the transformational mobile device is at the centre of human existence. As Sweet (2012) pertinently points out:

In thirty-five years, Martin Cooper's invention of the cell phone managed to lure more than half the human population into paying for active mobile-phone subscriptions. The adoption of the cell phone has been more than rapid, it has been rabid and revolutionary. Maslow's need hierarchy ought to be changed to breathing, food, water and phones. (n.p.)

\section{Movement to theory - Virtues of reality}

'I like living at the intersection of the humanities and technology' - said Steve Jobs in 2011 (Isaacson 2011).

\section{Practising theology as practical theology and practical reason}

Various (and sometimes even contrasting) discourses are accommodated within the field of practical theology $y^{5}$ (Ganzevoort 2009; Reader 2008:4). However, the name 4.For example Baumann (2007) and Joubert (2012).

5.'Practical theology is a term commonly used in Christian theology for a general way of doing theology concerned with the embodiment of religious belief in the day-today lives of individuals and communities' (Miller-McLemore 2012a:n.p.). 
'practical theology' suggests a concern with 'practice', thereby serving as a reminder that all theology is, in a sense, practical theology (Forrester 2000:3; LeRon Schults 2004:345). In the understanding of practice, space is created for a normative dimension, which is also theological in character.

In tracing ${ }^{7}$ the possible role of spirituality in fluid decisionmaking strategies in an era of virtuality, one of many possible lenses that offer a perspective on life, is investigated. The research focus is even further sharpened through the consideration of the consequences for the description of an embodied spirituality as manifested in decision-making strategies.

The investigation does not merely aim to theoretically explore the concept of spirituality, but rather to investigate the place and role of spirituality in fluid decision-making in an evolving world of virtuality. In the mapping out of the quest for a relevant practical theology, an affinity and congruence will be found with the recent accentuation of aspects such as social capital, spirituality, welfare, wellness and happiness (Graham 2011:224-225). The emphasis thus falls largely on the quest for avenues in which to record a spiritual orientation, and on the question of how such an orientation could inform 'practice for action, and not just any action but a particular kind of hard, often risky, intricate values-based action' (Gentile 2010:xi). ${ }^{8}$ Within the praxis of the era of virtuality, understood in the broadest possible terms, one of the relevant questions relates, precisely, to the way in which spirituality plays a role in fluid decisionmaking processes of the mobile virtual era. ${ }^{9}$

\section{Locus theologicus as praxis ${ }^{10}$}

With the accent on possible future developments in 'performing the faith' (Swinton \& Mowat 2006:4), an ebb and flow of 'belief-shaped practices' and 'practice-shaping beliefs' (Volf 2002:250-254) is mapped out. In these movements, a specific type of rationality comes to the fore, where the

6.'The turn to practice (and the desire to shape it) began to erase markers of difference between previously distinct areas, such as systematic and practical theology, ethics, sociology of religion, and even church history and religious studies ... In short, a wide-ranging number of intellectual developments inside and outside religious and theological studies ... intersected to generate fresh interest in practice, the study of practice, and the pursuit of improved pedagogical strategies for cultivating practical knowledge' (Miller-Mclemore 2012b:3).

7.'When I use the word "tracing", that is not only because it sounds so well in combination with sacred. It is especially because of the more than adequate meanings it carries. The first is the archaic meaning of traversing or travelling over a certain area. The second involves meanings like following or tracking the footprints of someone or something, like when on a hunt. Metaphorically, it can be transposed to study something in detail, like the history of an idea, the whereabouts of money moving around the world, or one's ancestry. It may also refer to the search for traces, signs, evidence, or remains of something that indicate a certain activity or presence. Tracing then has to do with reconstructing and developing knowledge. The last type of meanings has to do with drawing or sketching. It may be the careful forming of letters or figures or even certain kinds of decoration, but usually it is a form of copying by hand through a transparent sheet. Here tracing has to do with constructing, modelled after an external reality' (Ganzevoort 2009:5)

8.'... values-driven action is one of alignment, of moving with our highest aspirations and our deepest sense of who we wish to be, rather than a stance of coercion and stern judgement, or of moving against our inclinations' (Gentile 2010:28).

9.'Because communication is at the heart of human activity in all spheres of life, the advent of this technology, allowing multimodal communication from anywhere to anywhere where there is appropriate infrastructure, raises a wide range of fundamental questions' (Castells et al. 2007).

10.'When the term "praxis" is preferred to "practice", the emphasis is on the reflective or meaning content of behaviour, the integral interaction between theory and practice. Praxis usually refers to transformative practice' (Forrester 2000:7). 'human praxis of faith as a legitimate source of theological reflection' (Ganzevoort 2008:11-12) is presupposed, and in which 'embodied persons, and not abstract beliefs, should be seen as the locus of rationality' (Van Huyssteen 2006:77). It is therefore clear that the praxis terrain is of particular importance to practical theology, and that it attests to the conduction of a search aimed at 'tracing the sacred' in the 'hermeneutics of lived religion' (Ganzevoort 2009:1). Regarding a description of the condition of contemporary living, Elwell (2011) rightly indicates that:

From the Internet to the iPad that displays it, digital technology is no mere cultural artefact. It is the very condition of contemporary living. It affects how we experience and understand our world and ourselves at the deepest levels. Because it impacts such profound individual and cultural sensibilities, the digitization of modern life constitutes an essential field of religious concern. (p.11)

Strangely enough, this digitisation of modern life holds some implications for the traditional understanding of context. For the description of a praxis, of knowing, believing, and living in Africa, against the backdrop of an era of virtuality, the remarks by Strijbos (1998) regarding the decontextualised nature of technology are challenging:

Modern scientific technology is no longer tied to the practical, accumulated knowledge of particular cultures. Scientific knowledge has been cut free from such backgrounds and henceforth depends on general and abstract scientific knowledge. The link with science has given universality to technology, which was traditionally embedded in specific cultural situations. In this sense it can be said that technology has been decontextualized. The consequences of the decontextualization of technology have been far-reaching for the development of both technology and culture. (p. 336)

The aim of the planned research is therefore to trace the contours of spirituality within the digitalisation of life. It is envisaged that various online media (Potgieter 2012:23-35), will be studied in order to trace the contours of spirituality in fluid decision-making within the context of mobile virtuality. In order to engage with the praxis of decision-making in the era of virtuality, the emphasis falls on 'plausible forms of interdisciplinary dialogue' (Demasure \& Müller 2006:418). The quest for a relevant practical theology will be mapped out on the basis of an interdisciplinary dialogue between the Christian heritage and the focus domain of futures studies within the economic and management sciences. The recognition of the general human capacity to approach the future - which includes specific alternatives and choices and which is formed by structures, perceptions and forces - in a strategic and purposeful manner, falls within the domain of futures studies (Slaughter 2001:2; Lombardo 2008:15-16). In terms of this objective, the role of developing improved decision-making is emphasised.

\section{A virtual anthropology of spirituality?}

The research proceeds from the assumption that spirituality is a given that must be accounted for in the anthropological and contextual consideration of the human being (Schneiders 2005:26). Since we find ourselves in an era that is characterised 
by 'the impact of twenty-first-century technologies - digital, cybernetic and biomedical - upon our very understanding of what it means to be human' (Graham 2002:1), it is also necessary to consider the possible future impact of these technologies, in a responsible manner.

It is acknowledged that technology is not only increasingly challenging the limitations of the human brain and body, but is also changing the structure of life and society from an ecological point of view. Challies (2011) rightfully indicates that:

technologies cause biological change as the human body adapts to its most important influences ... technology tends to find ways of winning simply because we allow it to shape and re-create us at the deepest levels. As technology changes our biology, reshaping our brains, we become the product of our technologies in some deep and profound ways. (n.p.)

Following the trajectory of thought facilitated by the interdisciplinary discourse with futures studies, the contours of this investigation are not only to be found within the challenges and meaning of the present age of virtuality, but could also contribute to the mapping out of the considerable scholarly discussion regarding the movement toward a state of post-humanism (Lunceford 2009:77). When the term 'posthuman' or 'movement of singularity'11 is used, the condition referred to by writers and intellectuals, 'who envision a day when humans will virtually merge with their technology, thereby creating a new and superior posthuman species' (Waters 2006:x), is brought to mind. A futuristic possibility exists of 'scanning our consciousness into computers', enabling us to 'enter a virtual existence or swap our bodies for immortal robots and light out for the edges of space as intergalactic godlings' (Time Magazine 21 February 2011:27).

\section{Biographical decision-making}

In acknowledgement of the fact that even in the locus theologicus of virtuality, 'we all face momentous decisions at key turning points in our lives' (Liebert 2008), a biographical accent is emphasised. Not only has the biographical accent been emphasised in the virtual world of the social media, but according to Sweet (2012:n.p.), it will assume even greater importance: 'Status updates and tweets soon will be replaced by continuous "lifecasting" or "lifelogging". Everything you say or do will shape your personal brand, either making it more positive or negative.'

In the development of an 'ordinary theology' (Astley 2002), and with a distinct pragmatic accent on the need for academic theologians to become 'more curious about what ordinary believers have come up with' (Astley 2002:149), clear accentuations of functionality are emphasised. It is within these broader contours of a biographical description of life that the dynamics of the fluid decision-making in a mobile virtual reality will be investigated. Against the background

11. Raymond Kurzweil (2010), the father of the Singularity movement, comments that understanding Singularity will alter perspectives on the significance of our past and the ramifications of our future, pointing out that 'this is not because humans will have become what we think of as machines today, but rather machines will have have become what we think of as machines today, but rather machines will have
progressed to be like humans and beyond. Technology will be the metaphorical progressed to be like humans and beyond. Technology will
opposable thumb that enables our next step in evolution.' of the rich and diverse field of decision-making theory (Kahneman 2011), the research will focus particularly on the role played by spirituality in informing improved habitual decision-making. ${ }^{12}$ It is in this domain of focus that the interrelation between the new workplace and its challenges (Pembroke 2008:242) and life in general, as well as between fluid decision-making in the broadest sense of the word and spirituality ${ }^{13}$, will be demarcated.

\section{Movement from theory to practice - Virtual reality and the reality of virtues}

'The true digitalization of real life' (Nilesfilmfiles 2011).

\section{A virtual methodology}

Practical theology aims to investigate praxis empirically, and to interpret it in order to construct a theological framework within which it can be critically assessed by providing models of practice for future conduct and reform (Osmer 2006:329). Thus, the challenge for the practical theologian is to 'read' the praxis hermeneutically by moving between the empirical data and the sources of the Christian tradition (Ganzevoort 2003:77). The proposed research project on the possible role of spirituality in informing decision-making against the backdrop of mobile virtuality, embodies the character of a practical theological enquiry that is not only critical but also innovative (Swinton \& Mowat 2006). By way of the proposed method of transversal rationality, a practical theology is facilitated, which reflects an interdisciplinary way of thinking and acting between science and theology that is 'always concrete, local, and contextual', but which, nevertheless, also 'reaches beyond local contexts to transdisciplinary concerns' (Müller 2009:205).

With a view to entering this locus theologicus of virtuality, where practical theology indeed 'takes the praxis as its source and starting point' (Ganzevoort 2008:10), cognisance should be taken of Elwell's (2011) observation that:

New technologies impact us at the deepest and most profound levels. They construct what we do and how we do it. They inform our understanding of ourselves, each other, and our world. And ultimately they transform the very ways we think. (p. 10)

In the quest to develop approaches to interdisciplinary inquiry which are adequate for the specific situation, a predominantly narrative-informed biographical approach is followed. In the narration of stories in a variety of ways - ranging from fragments derived from an own life-text to those of co-researchers - as part of the documentation of the design, a contribution is made to a dynamic process of 'life writing' (Babbie \& Mouton 1998:502; Ganzevoort 2007:50).

12.The working mechanism between habitus and intuition is of importance for the investigation. 'Some intuitions draw primarily on skill and expertise acquired by repeated experience. The rapid and automatic judgments and choices of chess
masters, fireground commanders, and physicians ... in which a solution to the current problem comes to mind quickly because familiar cues are recognized' (Kahneman 2011).

13.The difference in character between intuitive decision-making (sometimes operating within a time frame of split seconds) and discernment (where patience and the luxury of time are of importance) is relevant in this regard. Both aspects are accommodated within the concept of habitus, as described earlier. 
In order to enter this praxis, it is envisaged that various online media (Potgieter 2012:23-35), such as social media, weblogs, wikis, virtual worlds and even gaming and so-called secondlife media, portraying biographical accents, will be studied in order to trace the contours of spirituality in fluid decisionmaking, in the context of mobile virtuality.

In the later stages of the envisaged research, new and experimental virtual realities such as Twitter and Second Life, ${ }^{14}$ and especially those that are administered on mobile platforms may be useful mediums in creating a space for further reflection on the research dynamics. ${ }^{15}$ Interestingly enough, new qualitative methodology currently already exists, and is being further developed in order to give researchers access to the content of these platforms ${ }^{16}$ via socalled computational linguistics.

\section{Tracing spirituality in the digitalisation of life}

Thus, in summary - on the basis of the foregoing - it is precisely from the locus theologicus of the 'medium-is-themessage' world (McLuhan \& Fiore 1967; Carr 2010) that the possibility, not only of tracing, but also of exploring the contribution of spirituality to the fluid decision-making of a mobile virtual reality, is envisaged. It is a search that can only be undertaken, in collaboration with people, as part of the everyday or 'ordinary' (Astley 2002:49).

In this ongoing endeavour, the nature of practical theology as 'a critical discipline which is prepared to challenge accepted assumptions and practises' (Swinton \& Mowat 2006:6-7), is accentuated. The research process therefore entails understanding, describing and possibly positively contributing to the habitus ${ }^{17}$ and its development as described, especially taking into account the role of spirituality in improved decision-making in a fluid world.

\section{Acknowledgements}

The research is supported by funding from the National Research Foundation of South Africa.

\section{Competing interests}

The author declares that he has no financial or personal relationship(s) which may have inappropriately influenced him in writing this article.

14.... virtual worlds - especially Second Life - are all about rules and roles. Virtual worlds are interactive narratives, and the avatars are actors in a kind of street theater where the audience helps improvise the plot' (Meadows 2008).

15.'Emergent research in virtual worlds is increasingly the result of collaboration between technologists and discipline specialists, crossing boundaries and producing an evidence base that is at the same time about the experience of the virtual and an extension of pedagogical practice and philosophy' (Peachey et al.).

16.'Chatterbox (2012) are developing a conversation platform which enables brands and corporations to identify and engage with their community of consumers in online interactive media such as Twitter and Facebook. Powered by recent research emerging from Queen Mary University of London, we enable corporations to find and support brand advocates and manage their brand reputation. We do this by and support brand advocates and manage their brand reputation. We do this by to extract the core users who drive brand conversation and opinion.'

17.Thus, Müller, Van Deventer and Human (2001:76-96) rightly point out that instead of working with hypotheses of what should be', it would be better 'to firstly understand the habitus, which refers to a kind of practical knowledge within which human social action ... constructs culture...

\section{References}

'2045. sin-gu-lar-i-ty n: The moment when technological change becomes so rapid and profound, it represents a rupture in the fabric of human history', Time Magazine, 21 February, 2011, pp. 20-27.

Anderson, K., 2011, 'Where two or more are gathered: Social media and ministry. iBelieve: Facing the New Media Media Explosion', Reflections-Yale Divinity School, Fall, 23-25.

Astley, J., 2002, Ordinary theology: Looking, listening and learning in theology: Explorations in practical, pastoral and empirical theology, Ashgate, Aldershot.

Babbie, E. \& Mouton, J., 1998, The practice of social research, Oxford University Press, Cape Town.

Barna, G., 2011, Futurecast: What today's trends mean for tomorrow's world, Tyndale House Publishers, Inc. New York. (Kindle edition).

Bauman, Z., 2007, Liquid Times: Living in Age of Uncertainty, Polity Press, Cambridge.

Bedford, N.E., 2002, 'Little moves against destructiveness: Theology and the practice of discernment', in M. Volf \& D.C. Bass (eds.), Practicing Theology. Beliefs and practices in Christian life, pp. 157-181, Wm. B. Eerdmans Publishing Co, Grand Rapids.

Bitterer, A. \& Sood, B., 2011, 'Mobile Business Intelligence, Finally', in Gartner, viewed 31 May 2012, from http://www.gartner.com/id=1840029.

Browning, D. S., 1991, A fundamental practical theology: Descriptive and strategic proposals, Fortress Press, Minneapolis.

Carr, N., 2010, The shallows: How the internet is changing the way we think, read and remember, Atlantic Books, London.

Castells, M., 2006, End of millennium: The information age: Economy, society and culture, vol. 3, 2nd edn., Blackwell Publishing, Oxford.

Castells, M. \& Fernandez-Ardevol, M. \& Linchuan Qiu, J. \& Sey, A., 2007, Mobile communication and society: A global perspective, The MIT Press, London. (Kindle edition).

Challies, T., 2011, The next story: Life and faith after the digital explosion, Zondervan, Grand Rapids. (Kindle edition).

Chatterbox, 2012, Who are we?, viewed 31 May 2012, from http://chatterbox.co.

Demasure, K. \& Müller, J., 2006, 'Perspectives in support of the narrative turn in pastoral care', Nederduitse Gereformeerde Teologiese Tydskrif 47(3/4), 410-419.

Dykstra, C. \& Bass, D.C., 2002, 'A theological understanding of Christian Practices', in M. Volf \& D.C. Bass (eds.), Practicing Theology: Beliefs and practices in Christian life, pp. 13-32, Wm. B. Eerdmans Publishing Co, Grand Rapids.

Elwell, J.S., 2011, Crisis of transcendence: A theology of digital art and culture, Lexington Books, Lanham.

Forrester, D.B., 2000, Truthful action: Explorations in Practical Theology, T\&T Clark, Edinburgh.

Friedman, T.L., 2006, The world is flat: A brief history of the twenty-first century, Farrar, Strauss and Giroux, New York.

Ganzevoort, R.R., 2003, 'Models for practical ministry: Methodological considerations pertaining to the construction of models from the description of the situation and its theological interpretation', in R.R. Ganzevoort \& S. Fazakas (eds.), Amt und Professionalität: Ministeriality and Professionality. Papers of a Working Conference pp. 77-84, n.p.

Ganzevoort, R.R., 2007, 'Waarheen met de praktische theologie?', Theologisch Debat $4(1), 20-24$

Ganzevoort, R.R., 2008, 'Teaching that matters: A course on trauma and theology' Journal of adult theological education 5(1), 8-19. http://dx.doi.org/10.1558/ jate2008v5i1.8

Ganzevoort, R.R., 2009, 'Forks in the road when tracing the sacred. Practical theology as hermeneutics of lived religion', Presidential address to the ninth conference of the International Academy of Practical Theology, Chicago 2009, viewed 24 April 2010, from http//www.ruardganzevoort.nl

Gentile, M.C., 2010, Giving voice to values: How to speak your mind when you know what's right, Yale University Press, New Haven.

Glenn, J.C., Gordon, T.J. \& Florescu, E., 2008, State of the Future, The Millennium Project, World Federation of UN Associations, Washington.

Graham, E.L., 2002, Representations of the Post/Human: Monsters, aliens and others in popular culture, Rutgers University Press, New Jersey.

Graham, E.L., 2003, 'Frankensteins and cyborgs: Visions of the global future in an age of technology', Studies in Christian Ethics 16(1), 29-43. http://dx.doi. an age of technology', Studies in Christian Ethics
org/10.1177/095394680301600103, PMid:14686330

Graham, E., 2011, 'The "virtuous circle": Religion and the practices of happiness', in J. Atherton, E. Graham \& I. Steedman (eds.), The practices of happiness: Political economy, religion and wellbeing, pp. 224-234, Routledge, London.

'"Help, sheep missing": How Twitter is fighting crime in Kenya', 2012, The Telegraph, 20 February, 2012, viewed 14 June 2012, from http://www.telegraph.co.uk/ technology/twitter/9092988/Twitter-Chief-Kariuki-fights-crime-in-Kenya.html

Ipsos. Home of Researchers, 2012, 'If South Africa was a village ... What would it look like?', viewed 28 April 2012, from http://ipsos-markinor.co.za/news/if-southafrica-was-a-village-what-would-it-look-like

Isaacson, W., 2011, Steve Jobs, Hachette Digital, London. (Kindle edition).

Joubert, S.J., 2010, 'Annus Virtualis: Enkele uitdagings wat die virtuele era van Web 2.0 aan relevante kerklike bedieninge stel', Nederduitse Gereformeerde Teologiese Tydskrif 51(3/4), 48-60. 
Joubert, S.J., 2012, Not by dialogue, nor by order or simplicity: The metanoetic presence of the kingdom of God in a fluid world, Inaugural lecture as extraordinary professor, Faculty of Theology, University of the Free State, Bloemfontein on 09 professor,
May 2012.

Kahneman, D., 2011, Thinking fast and slow, Penguin , London. (Kindle edition).

Kurzweil, R., 2010, The singularity is near, Gerald Duckworth, London. (Kindle edition).

Le Ron Schults, F., 2004, 'The philosophical turn to relationality and the responsibility of practical theology', in D.R. Wright \& J.D. Kuentzel (eds.), Redemptive Transformation in Practical Theology: Essays in honor of James E. Loder jr., pp. 325-346, William B. Eerdmans Publishing Company, Grand Rapids.

Lesame, Z., Sindane, S. \& Potgieter, P., 2012, 'New media: Theories and applications', in Z. Lesame, B. Mbatha \& S. Sindane (eds.), New media in the information society, pp. 1-21, Van Schaik Publishers, Pretoria.

Liebert, E., 2008, The way of discernment, John Knox Press, Westminster. (Kindle edition).

Lombardo, T., 2008, The evolution of future consciousness, Authorhouse, Bloomington.

Lunceford, B., 2009, 'The body and the sacred in the digital age: Thoughts on posthuman sexuality', Theology \& Sexuality 15(1), 77-96. http://dx.doi org/10.1558/tse.v15i1.77

MacIntyre, A., 1981, After Virtue, 2nd edn., University of Notre Dame Press, Notre Dame, IN.

McLuhan, M. \& Fiore, Q., 1967, The medium is the message, Random House, New York.

Meadows, M.S., 2008, l, avatar: The culture and consequences of having a second life, Newriders, Berkeley. (Kindle edition)

Miller-McLemore, B.J., 2012a, Christian Theology in Practice: Discovering a discipline William B. Eerdmans Publishing Company, Grand Rapids. (Kindle edition).

Miller-McLemore, B.J., 2012b, 'Introduction: The contributions of practical theology', in B.J. Miller-McLemore (ed.), The Wiley-Blackwell Companion to Practical Theology, pp. 1-20, Blackwell Publishing, Oxford.

Müller, J., 2009, 'Transversal Rationality as a practical way of doing interdisciplinary work, with HIV and Aids as a case study', Practical Theology in South Africa 24(2), 199-228.

Müller, J.C., \& Van Deventer, W., \& Human, L., 2001, 'Fiction writing as metaphor for research: A narrative approach', Practical Theology in South Africa 16(2), 76-96.

Niemandt, C.J.P., 2009, 'John Calvin and the church in a time of transition', Nederduitse Gereformeerde Teologiese Tydskrif 50(3/4), 620-633.
Nilesfilmfiles, 2011, 'Revolutions-and-revelations-oscars-for', viewed 23 May 2011 from http://nilesfilmfiles.blogspot.com/2011/02/revoltions-and-revelations-oscarsfor.html

Osmer, R.R., 2006, 'Toward a transversal model for interdisciplinary thinking in practical theology', in F. Leron Schults (ed.), The evolution of rationality: Interdisciplinary essays in honor of J. Wentzel van Huyssteen, pp. 327-345, Wm. B. Eerdmans Publishing Co, Grand Rapids.

Osmer, R., 2008, Practical Theology: An introduction, Wm B. Eerdmans, Grand Rapids.

Peachey, A., Gillen, J., Livingstone, D. \& Smith-Robbins, S., 2010, Researching Learning in Virtual Worlds, Springer, London. (Kindle edition).

Pembroke, N., 2008, 'Partnership in the Workplace: Covenant and ManagementLabour Relations', International Journal of Practical Theology 12, 242-255. http:// dx.doi.org/10.1515/IJPT.2008.11

Potgieter, P., 2012, 'An overview of online new media', in Z. Lesame; B. Mbatha \& $\mathrm{S}$. Sindane (eds.), New media in the information society, pp. 23-35, Van Schaik Publishers, Pretoria.

Reader, J., 2008, Reconstructing practical theology: The impact of globalization, Ashgate, Aldershot.

Schneiders, S.M., 2005, 'The study of Christian spirituality', in A. Holder (ed.), The Blackwell companion to Christian spirituality, pp. 15-33, Blackwell Publishing, Oxford.

Slaughter, R.A., 2001, 'Knowledge creation, futures methodologies and the internal agenda', Foresight 35, 407-418. http://dx.doi.org/10.1108/14636680110697129

Sweet, L., 2012, Viral: How social networking is poised to ignite revival, Waterbrook Press, Colorado Springs. (Kindle edition).

Strijbos, S., 1998, 'The problem of development and the decontextualization of technology: A world-system approach', World Futures: The Journal of Global Education 52(3/4), 333-346.

Swinton, J. \& Mowat, H., 2006, Practical theology and qualitative research, SCM Press, London.

Tweetsmarter, 2012, First map of Twitter use in Africa, viewed 14 June 2012, from http://blog.tweetsmarter.com/twitter-stats/first-map-of-twitter-use-in-africa/

Van Huyssteen, J.W., 2006, Alone in the world? Human Uniqueness in Science and Theology: The Gifford Lectures, Wm. B. Eerdmans, Grand Rapids.

Volf, M., 2002, Theology for a Way of Life, in M. Volf \& D.C. Bass (eds.), Practicing Theology: Beliefs and practices in Christian life, pp. 245-263, Wm. B. Eerdmans Publishing Co., Grand Rapids.

Waters, B., 2006, From human to posthuman: Christian theology and technology in a postmodern world, Ashgate, Aldershot. 